\title{
Response of the Mongolian gerbil uterus to oestradiol-17 $\beta$ at various times after ovariectomy
}

\author{
D. A. Brown and K. V. Prahlad \\ Department of Biological Sciences, Northern Illinois University, DeKalb, Illinois 60115, U.S.A.
}

\begin{abstract}
Summary. Treatment of ovariectomized gerbils with $2 \mu$ g oestradiol-17 $\beta /$ day for 3 days resulted in decreasing alkaline phosphatase activity in the uterus at 15 days, 30 days, 3 months and 18 months. Relative uterine weight decreased at 3 months but increased at 18 months.
\end{abstract}

It is known that there is a decrease in the sensitivity of target tissues to exogenous hormones as the time after removal of the endogenous source of trophic hormones increases (Liddle, Island \& Meador, 1962; Clare, Massons \& Roberte, 1967; Davidson, 1969; Davidson \& Bloch, 1969; Damassa \& Davidson, 1973). No information is available about the response of the gerbil uterus to oestradiol after ovariectomy and we therefore investigated the uterine sensitivity at various times after ovariectomy.

Mongolian gerbils, Meriones unguiculatus, were obtained from the departmental colony. Virgin females about 8 weeks of age were ovariectomized using ether anaesthesia and caged in groups of four, in the same room as, but not in close contact with, males. Completeness of ovariectomy was checked by vaginal smears taken from all animals for at least 7 days before the start of the injections. There were 5-8 animals in each group and the interval between ovariectomy and death was 15 days, 30 days, 3 months or 18 months. For 3 days before being killed the animals were given a s.c. injection at $08.00 \mathrm{~h}$ of $2 \mu \mathrm{g}$ oestradiol-17ß dissolved in $0.05 \mathrm{ml}$ sesame oil; control animals received oil only.

The animals were weighed and killed by cervical dislocation $72 \mathrm{~h}$ after the first injection and changes in relative uterine weight and concentration of uterine alkaline phosphatase were studied. The uterus was excised immediately, stripped of any adhering connective tissues, and the luminal fluid was gently expressed. After weighing, comparable segments were removed from the uteri of control and experimental animals for examination. These sections were placed in $10 \%$ formalin, and the rest of the uterine tissue was weighed again. The alkaline phosphatase content was determined as described previously (Prahlad \& Conaway, 1961). Results were statistically analysed by the StudentNewman-Keuls multiple-range test (Zar, 1974).

The control uteri were very small, with no signs of fluid accumulation or hyperaemia. The experimental uteri were fluid-filled, but exhibited very little, if any, hyperaemia. The relative uterine weight declined during the first 3 months after ovariectomy but by 18 months after ovariectomy the ability of the uterus to respond to the hormone appeared to be regained (Table 1). There was a dramatic increase in alkaline phosphatase activity in oestradiol-treated animals compared with that in the oil-injected controls (Table 1). Also, as the time after ovariectomy increased, the ability of the uterus to respond to the hormone decreased.

In the oestrogen-treated animals the diameter of the uterus was much greater than that of the corresponding control uteri and the endometrium was thicker and more glandular. As expected the epithelial lining of the lumen was columnar in treated animals.

These results are in partial agreement with the work of others. Damassa \& Davidson (1973) found that uterine weight was increased significantly more in rats treated with hormones immediately after castration than in those which were treated 6 weeks after operation. Peng \& Peng (1973) have also shown that rats in prolonged anoestrus (indicating absence of oestrogen) or with prolonged vaginal cornification (indicating presence of oestrogen) responded differently to oestradiol-17 $\beta$ after ovariectomy: there was a greater response to the hormone in the latter than in the former. 
Table 1. The effect (mean \pm S.E.M.) on ovariectomized Mongolian gerbils (5-8/group) of oestradiol treatment at different times after ovariectomy

\begin{tabular}{|c|c|c|c|c|}
\hline & \multicolumn{4}{|c|}{ Time after ovariectomy } \\
\hline & 15 days & 30 days & 3 months & 18 months \\
\hline \multicolumn{5}{|c|}{$\begin{array}{l}\text { Reiative uterine weight }(\mathrm{mg} / 100 \mathrm{~g} \\
\text { body wt) }\end{array}$} \\
\hline $\begin{array}{l}\text { Control } † \\
\text { Experimental }\end{array}$ & $\begin{array}{r}21.21 \pm 0.75 \\
100 \pm 7.25 \ddagger\end{array}$ & $\begin{array}{l}18 \cdot 75 \pm 1 \cdot 25 \\
80 \cdot 65 \pm 3 \cdot 75\end{array}$ & $\begin{aligned} 15 & \pm 1 \cdot 25 \\
65 \cdot 65 & \pm 4 \cdot 4\end{aligned}$ & $\begin{array}{r}24 \pm 0.75 \\
86 \cdot 56 \pm 2 \cdot 81\end{array}$ \\
\hline \multicolumn{5}{|c|}{$\begin{array}{l}\text { Alkaline phosphate content (units } * 100 \\
\text { mg tissue) }\end{array}$} \\
\hline Control $†$ & $3 \cdot 75 \pm 0 \cdot 25$ & $1 \cdot 5 \pm 0.3$ & $1.13 \pm 0.25$ & $3.08 \pm 0.5$ \\
\hline Experimental & $22 \cdot 31 \pm 2 \cdot 33 \S$ & $18.5 \pm 2.08$ & $15 \cdot 25 \pm 1 \cdot 18$ & $11.63 \pm 1.0$ \\
\hline
\end{tabular}

* One unit represents the amount of enzyme activity which will release $1 \mathrm{mmol} p$-nitrophenol under the specified conditions.

+ All control values were significantly $(P<0.01)$ lower than those of the experimental animals.

¥ This value was significantly $(P<0.01)$ higher than those at 30 days and 3 and 18 months; values at 30 days and 18 months were not significantly different.

$\S$ This value was significantly $(P<0.01)$ higher than those at 30 days and 3 and 18 months.

Our findings of a decreased response of the uterus in the first 3 months after ovariectomy agree with those of other workers (see above). However, at 18 months after ovariectomy the relative uterine weight was not significantly different from that at 15 days but the alkaline phosphatase activity was at its lowest level. This suggests that, if oestrogen uptake is similar at all times after ovariectomy, as shown by Peng \& Peng (1973), the difference between the uterotrophic and biochemical response must be caused by oestrogen acting in more than one way.

\section{References}

Clare, J., Massons, J.M., \& Roberte, T. (1967) Accion de los androgenos sobre prostata y vesiculas seminales en la rata macho castrada. Rev. Espan. Fisiol. 23, 115-116.

Damassa, D. \& Davidson, J.M. (1973) Effects of ovariectomy and constant light on responsiveness to estrogen in the rat. Horm. \& Behav. 4, 269-279.

DAvidson, J.M. (1969) Feedback regulation of gonadotropin secretion. In Frontiers in Neuroendocrinology, pp. 343-389. Eds W. F. Ganong \& L. Martini. Oxford University Press.

Davidson, J.M. \& BLOCH, G.J. (1969) Neuroendocrine aspects of male reproduction. Biol. Reprod. 1, 67-92.
Liddle, G.W., Island, D. \& MEAdoR, C.K. (1962) Normal and abnormal regulation of corticotropin secretion in man. Recent Prog. Horm. Res. 27, 125-167.

Peng, M.T. \& Peng, Y.M. (1973) Changes in the uptake of tritiated oestradiol in the hypothalamus and adenohypophysis of old female rats. Fert. Steril. 24, 534-539.

Prahlad, K.V. \& Conaway, C.H. (1961) Alkaline phosphatase activity in the rat uterus. $J$. Embryol. exp. Morph.9, 599-608.

ZAR, J.H. (1974) Biostatistical Analysis. Prentice Hall, Englewood Cliffs, New Jersey. 